\title{
Previous Research Works on Reinforced Concrete Curved Beams
}

\author{
W. H. Khaleel ${ }^{1}$, A. A. Talal ${ }^{1}$, N. H. Baidaa ${ }^{1}$, K. S. Abdul-Razzaq ${ }^{1, a^{*}}$, and A. A. \\ Dawood $^{1}$ \\ ${ }^{1}$ Civil Engineering Department, University of Diyala, Diyala, 32001, Iraq.
}

adr.khattabsaleem@yahoo.com

\begin{abstract}
The current research work summarizes some previous research works on horizontally curved beams. Because of curvature, torsional effects in the analysis and design should be included. Diameter of ring beam, number of supports, beam width, compressive strength of the concrete, and bearing plate width. Which can be summarized from previous studies is that increasing diameter of ring by about $25-75 \%$ decreases the capacity load by about $14-36 \%$, while increasing number of supports by about $33-100 \%$, beam width by about $25-75 \%$, compressive strength of concrete by about $24-76 \%$, and bearing plate width by about $25-75 \%$ increases the capacity load by about $62-189 \%, 25-$ $75 \%, 24-76 \%$, and $5-16 \%$, respectively due to the beam section increase and/or its properties. Frequently, reinforced concrete deep ring beams exhibit shear failure in a manner similar to straight beams. Strut and tie model (STM) and plastic analysis are useful tools for efficiently analyzing ring or curved deep beams. In addition, the nonlinear three-dimensional finite element modeling is typical for predicting the deep curved beams strength and behavior.
\end{abstract}

Keywords: Previous research works; reinforced concrete; curved, ring; beams.

\section{Introduction}

Unlike a straight beam, the beam section center does not coincide with the total beam center in a horizontally curved beam. Furthermore, neutral axis stresses do not vary linearly. Torsional moments occur in a ring beam because the reactions and applied loads do not lie at the ring beam's main axis [1]. At the mid-span between any two successive supports, torsional moments are zero in the case of a circular beam with equally spaced supports. Torsional moments maximum values develop at the contra flexure points [2]. Ring beams may be constructed in circular reservoirs, domes, offshore structures, silos, and many other constructions. Shallow rather than deep ring beams are usually constructed to have heavy load capacity [3]. Reinforcement is a major feature in the ring and curved beams improvement - for easier constructing, $\mathrm{RC}$ is frequently used for deep curved ring beam members. And yet, the lateral loading impact on the failure mode, pattern of cracking, and ultimate capacity of RC ring beams have been realized [4].

In addition to the curvature, the depth of the section is also very important. The ACI $318 \mathrm{M}-19$ Code describes deep beams as [5]: "the structural members supported on a face and loaded on the opposite face such that shear stresses can develop between the supports and loads. That satisfies (a) or (b): (a) Single forces lie in a distance $2 \mathrm{~h}$ from support face, and (b) Clear span is not more the four times the depth of the member h". Strut and tie modeling (STM) is considered one of the most influential approaches to analyze RC deep beams where D regions occur [6-15]. The STM approach assumes a truss that contains compression members (struts) that are linked to tensile members (ties) in specific points (nodes) [16-29].

Plastic analysis is another key method where ultimate capacity load and plastic hinge are considered as foremost considerations of design. A plastic hinge is a conceded point where rotations and moves can happen because of bending. Various moments types take place in curved or ring beams; consequently, plastic analysis can be efficiently taken into considerations here. The finite difference method (FDM) and finite element method (FEM) is also frequently used to analyze such as members. Though, both FDM and FEM frequently need expensive improvements to achieve precise results, as they characteristically use schemes of low-order. Notwithstanding the profusion of investigations that concern ring or curved beams, there is a research work obvious deficiency that 
deal with RC ring deep or curved beams. The most significant of the few available investigations will be briefly said here.

\section{Precedent Curved Beams Researching Works}

In 1977, Badawy et al. [30] studied the combined effect of torsion, shear, and bending on RC beams by two yield criteria plastic analysis. Totally, fifteen beam specimens were tested, seven straight beams and eight curved beams with a $2.21 \mathrm{~m}$ radius and an angle of 75 degrees as presented in Figure 1. 1-concentrated load was used to test all specimens. Four curved specimens were tested using various end conditions. They were reinforced conventionally. Both the end conditions and the transverse reinforcement were changed among the curved specimens. The straight specimens were also reinforced conventionally and tested using different bending, shear and torsion combinations. That was conducted to find where the two criteria of yield overlapped with torsion, shear and bending axes. The straight beams were similarly tested to check the criteria of yield when used in the case of the curved beams.

The plastic analysis of Badawy et al. explained the behavior of beams through the combintion of only bending and torsion, i.e., in the first criterion, shear is ignored. Analyzing process was then developed to include the effect of shear, and the early outcomes were associated with the outcomes of shear inclusion. After that, the researchers added the effect of shear in the research work both prestressed and reinforced concrete. Badawy et al. investigated the patterns of crack, the beams distortion, and the strain values in steel bars of curved beams to find the moments of the plastic hinge and thus analyze failure modes. The plastic hinge types - either shear-torsion hinges, hinges of flexure, or torsion- bending-shear hinges - were similarly investigated. The test outcomes of the experimental work were compared with the plastic theory results. Based on that, the main concluding remarks were:

1) The approach of the plastic analysis is a good solution for RC curved beams.

2) Using (bending and torsion only) criterion is a good load capacity predication, internal forces, and failure mode. Though, the (including shear) analysis criterion establishes a member nominal strength for the interior forces and the ultimate load. The equations of dimensionless for the both surfaces are:

$$
\begin{aligned}
& m^{2}+t^{2} /\left(1-v^{2}\right)=1, \quad 1^{\text {st }} \text { criterion of yield and } \\
& m^{2}+t^{2} /(1-v)^{2}=1, \quad 2^{\text {nd }} \text { criterion of yield }
\end{aligned}
$$

where $=T / T_{P}, m=M / M_{P}, v=V / V_{P} ; \mathrm{T}, \mathrm{V}$ and $\mathrm{M}$ are torsion, shear and moment; and $T_{P}, V_{P}$ and $M_{P}$ are the associated plastic capacities of cross-section in torsion, shear and pure bending.

3) Two types of redistribution of interior forces occur in a curved beam; the $1^{\text {st }}$ due to cracking and $2^{\text {nd }}$ due to the plastic hinge development.

4) The plastic analysis precisely predicts failure modes. 




Figure 1. Test specimens machine [30].

In 2020, Abdul-Razzaq et al. [31] used STM to study the most effective parameters on the strength and behavior of two-span deep ring beam (20 specimens), Table 1. In Group A, diameters were varied; $1,1.25,1.5$, then $1.75 \mathrm{~m}$. In Group B, the number of supports was varied gradually from three to six. In Group C, various width values of ring beam were taken into consideration; $0.1,0.125,0.15$, and $0.175 \mathrm{~m}$. In Group D, concrete compressive strength values were varied; 25, 31, 38, and $44 \mathrm{MPa}$. In Group E, different bearing plate width values were adopted; 100, 125, 150, and $175 \mathrm{~mm}$. The main conclusions that were presented by Abdul-Razzaq et al.:

1) Load capacity reduction takes place because of increasing the ring beam diameter (increasing $\mathrm{a} / \mathrm{h}$ ratio). In the language of numbers, increasing the diameter of the ring by $25-75 \%$ reduces the capacity of load by $14-36 \%$. This reduction occurs due to rising the (arc shear to whole height) ratio. Rising $\vartheta h / \vartheta v$ (center horizontal to perpendicular angle) ratio, increases the compressive strut length and decreases the angle between strut and tie.

2) When the number of supports increases, the capacity of load increases. More specifically, capacity of ring load increase by $62.04-188.86 \%$ when rising the number of supports by $33.33-100 \%$. This tool is placed due to the fact that increasing the inclined struts number and rising the angle between strut and tie results a length of strut decrease, reducing the arc shear to whole height ratio, which reduces $\vartheta h / \vartheta v$ ratio of (center horizontal to perpendicular angle).

3) Ring capacity of load is directly proportional to width of beam. In the language of numbers, increasing width values of the beam by about $25-75 \%$ increases the capacity load of the beam by $25-75 \%$. That takes place because of the direct relationship between the strut section dimensions and the width of the beam, tie, and the related node's faces.

4) Rising compressive concrete strength by $24-76 \%$, the struts strength and the related nodes develops, leading to rise the capacity of load by $24-76 \%$.

5) When the bearing plate width increases by $25-75 \%$, the ring beam capacity of load increases by $5.3-15.85 \%$, as struts and nodes are strengthened.

Table 1. Parametric study [31]. 


\begin{tabular}{|c|c|c|c|c|c|c|c|c|c|}
\hline 言 & 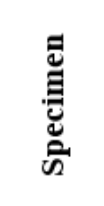 & $\begin{array}{c}\text { Total } \\
\text { depth } \\
(h) \\
\text { mm }\end{array}$ & $\begin{array}{c}\text { Arc } \\
\text { Shear } \\
\text { Span } \\
(a) \\
\text { mm }\end{array}$ & $\begin{array}{c}\text { Ring } \\
\text { diameter } \\
(D c) \\
\text { mm }\end{array}$ & $\begin{array}{c}\text { Number } \\
\text { of } \\
\text { support }\end{array}$ & $\begin{array}{l}\text { Width of } \\
\text { specimen } \\
\text { (bw) } \mathrm{mm}\end{array}$ & $\begin{array}{c}\text { Compressive } \\
\text { Strength } \\
\left(f^{\prime} c\right) \text { MPa }\end{array}$ & $\begin{array}{l}\text { Width of } \\
\text { Bearing } \\
\text { Plate } \\
(B p) \mathrm{mm}\end{array}$ & Parameter \\
\hline \multirow{4}{*}{$\mathbf{A}$} & $\mathrm{RD1}$ & 500 & 523.33 & 1000 & 3 & 150 & 31 & 150 & \multirow{4}{*}{$\begin{array}{c}\text { Ring } \\
\text { diameter }\end{array}$} \\
\hline & $\mathrm{RD} 2$ & 500 & 654.17 & 1250 & 3 & 150 & 31 & 150 & \\
\hline & RD3 & 500 & 785 & 1500 & 3 & 150 & 31 & 150 & \\
\hline & RD4 & 500 & 915.83 & 1750 & 3 & 150 & 31 & 150 & \\
\hline \multirow{4}{*}{ B } & RD5 & 500 & 654.17 & 1250 & 3 & 150 & 31 & 150 & \multirow{4}{*}{$\begin{array}{c}\text { Number of } \\
\text { support }\end{array}$} \\
\hline & RD6 & 500 & 490.63 & 1250 & 4 & 150 & 31 & 150 & \\
\hline & RD7 & 500 & 392.5 & 1250 & 5 & 150 & 31 & 150 & \\
\hline & RD8 & 500 & 327.08 & 1250 & 6 & 150 & 31 & 150 & \\
\hline \multirow{4}{*}{ C } & RD9 & 500 & 654.17 & 1250 & 3 & 100 & 31 & 150 & \multirow{4}{*}{$\begin{array}{l}\text { Width of } \\
\text { specimen }\end{array}$} \\
\hline & RD10 & 500 & 654.17 & 1250 & 3 & 125 & 31 & 150 & \\
\hline & RD11 & 500 & 654.17 & 1250 & 3 & 150 & 31 & 150 & \\
\hline & RD12 & 500 & 654.17 & 1250 & 3 & 175 & 31 & 150 & \\
\hline \multirow{4}{*}{ D } & $\overline{\mathrm{RD} 13}$ & 500 & 654.17 & 1250 & 3 & 150 & 25 & 150 & \multirow{4}{*}{$\begin{array}{l}\text { Compressive } \\
\text { Strength }\end{array}$} \\
\hline & RD14 & 500 & 654.17 & 1250 & 3 & 150 & 31 & 150 & \\
\hline & RD15 & 500 & 654.17 & 1250 & 3 & 150 & 38 & 150 & \\
\hline & RD16 & 500 & 654.17 & 1250 & 3 & 150 & 44 & 150 & \\
\hline \multirow{4}{*}{$\mathbf{E}$} & $\overline{R D 17}$ & 500 & 654.17 & 1250 & 3 & 150 & 31 & 100 & \multirow{4}{*}{$\begin{array}{c}\text { Width of } \\
\text { Bearing Plat }\end{array}$} \\
\hline & RD18 & 500 & 654.17 & 1250 & 3 & 150 & 31 & 125 & \\
\hline & RD19 & 500 & 654.17 & 1250 & 3 & 150 & 31 & 150 & \\
\hline & RD20 & 500 & 654.17 & 1250 & 3 & 150 & 31 & 175 & \\
\hline
\end{tabular}

In 1981, Mansur and Rangan [32] investigated about three different RC horizontally curved beam design methods:

1) An approach of demolishing load was recommended by Badawy et al. [30].

2) The classic elastic approach based on sections that were not cracked.

3) An approach of limit design recommended by Mansur and Rangan [32].

The above points were taken into consideration in studying the effect of steel reinforcements, strength and mode of failure, and curved beams. Two additional conditions were used for limit design method of Mansur and Rangan's in the statically indeterminate system of design. The $1^{\text {st }}$ extra condition was offered via assuming a torsional ultimate design moment:

$$
T_{u}=\left[0.33 \sqrt{f^{\prime}}{ }_{c} x_{1}^{2} y_{1} / 3\right] \text { in (N.mm) at sections that considered critical, }
$$

where $x_{1}$ and $y_{1}$ are the lesser and the greater dimensions, of a section of rectangle $(\mathrm{mm})$, and $f_{c}^{\prime}$ is the compression strength of concrete (MPa). According to elastic analysis, the 2nd additional condition was offered based on assuming a position of inflection point (where the bending moments vanish). The fixed supports beams radius values were $2.45 \mathrm{~m}$ and 90 degrees subtended angle, Figure 2. The main concluding remarks were:

1) In a RC curved beam, 2 key moments produce redistribution in interior forces. After cracking $1^{\text {st }}$ stage, and the plastic hinges development, $2^{\text {nd }}$ stage according to Badawy et al. [30].

2) Though all 3 approaches led to RC concrete beams satisfactory results, Badawy et al.'s approach was the minimum effective based on use of steel. Using a collapse load approach, the designed beam specimens required a higher steel ratio (principally rings made by steel) in comparison with the other 2 approaches. 


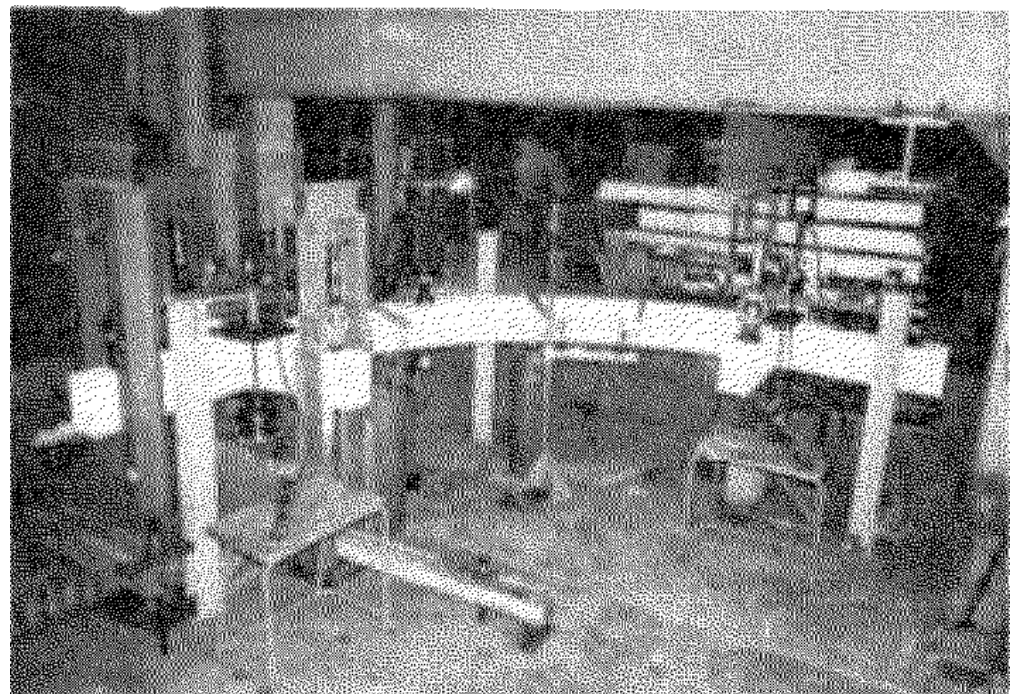

Figure 2. Test setup of beams [32].

In 2013, Al-Mutairee [33] studied making RC curved beams optimal strength using longitudinal reinforcement non-uniform layout without increasing the longitudinal reinforcement volume. The 3D nonlinear finite element analysis computer software was used for a beam curved horizontally tested using static load. The study indicated that in RC fixed-ends beams that curved horizontally, Figure 3, the use of longitudinal reinforcement in non-uniform distribution is adequate. The ultimate load capacity was enhanced, progressively significant with increasing the horizontal angle of curvature $(\theta)$.

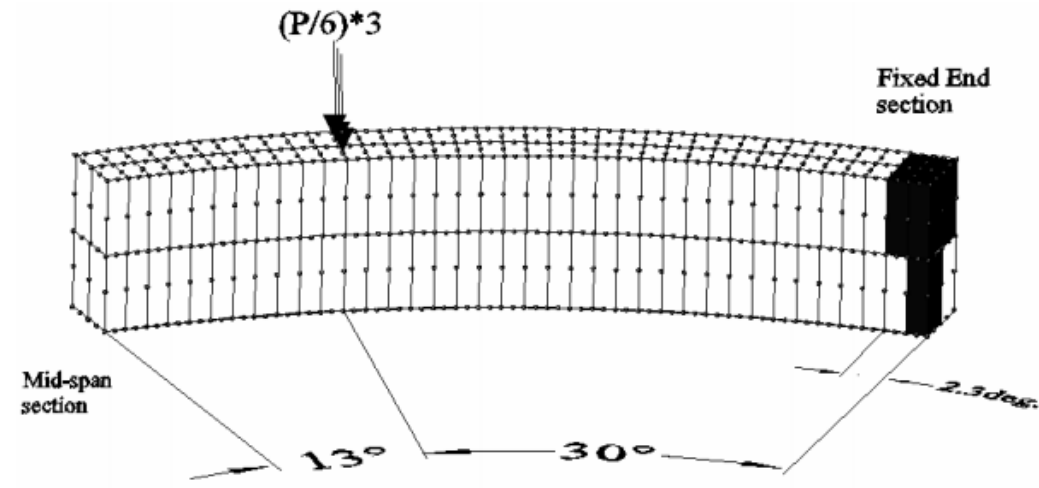

Figure 3. The elements suffer from the ruptured of longitudinal reinforcement [33].

In 2011, Al-Azzawi and Shaker [34] studied the effect of elastic foundations with friction and compression resistance on the deep beams that curved horizontally, elasticity. The Timoshenko's theory concerning deep beam is developed to cover the effect of curvature and forces that distributed externally. So allowing curved beams analysis in static conditions. Al-Azzawi and Shaker used the finite difference technique for curved deep beams modeling; they verified results with other approaches. The vertical reaction of subgrade, horizontal reaction of subgrade, beam width, and ratio of beam thickness/radius were all involved to study their effect on the shear forces, bending moments and the deflections. Al-Azzawi and Shaker checked the results by comparing them with experimental and other theoretical results. The max difference percentages for deflections in addition to moments were 5.3 besides $7.3 \%$, respectively, proving the efficacy of their analysis approach. Their parametric study indicated that:

1) Under 4 concentrated forces on free curved beam, as shown in Figure 4, increasing the ratio of thickness/radius $(0.1-1)$, reduces the maximum deflection by $63.5 \%$.

2) Under 4 concentrated forces, increasing the width of the free curved beam $(62-3048) \mathrm{mm}$, reduces the maximum deflection by about $75 \%$. 
3) The maximum deflection decreases when the vertical and horizontal subgrade reactions rise. The increase in the reactions of horizontal subgrade will practically reduce the maximum deflection in a linear manner.

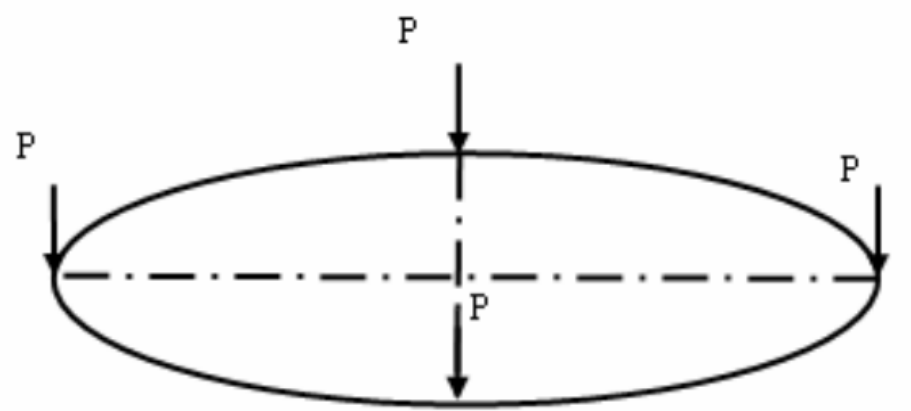

$$
\begin{aligned}
& P=667.5 \mathrm{kN} \\
& R=7629.45 \mathrm{~mm} \\
& b=762 \mathrm{~mm} \\
& \mathrm{~h}=762 \mathrm{~mm} \\
& E=20.7 \mathrm{kN} / \mathrm{mm}^{2} \\
& \mathrm{~K}_{\mathrm{s}}=0.135^{*} 10^{-4} \mathrm{kN} / \mathrm{mm}^{3} \\
& \mathrm{v}=0.15 \\
& \mathrm{~A}=580644 \mathrm{~mm}^{2}
\end{aligned}
$$

Figure 4. Ring beam on an elastic foundation under four concentrated loads [34].

In 2014, Al Qaicy et al. [4] analyzed three concrete ring beam specimens supported by four equally spaced $3 \mathrm{~m}$ height columns using nonlinear finite element analysis (NLFEA). The varied parameters were the beam depth 500, 1000, and $2000 \mathrm{~mm}$ and reinforcement ratio. They studied the mode of failure, ultimate load strength, deformation shape at the collapse point, and patterns of cracks. Al Qaicy et al. concluded that the ring beams failure modes are mainly affected by the ratio of depth/span (in this study, the ratio of span/depth looks like that in non-curved beams). Authors reached that fact that the deep ring beams fail in shear, whereas the shallower ones fail in flexure. That also takes place in non-curved beams. The stiffening rate of tension fluctuated $(0.002-0.003)$.

In 2002, Al-Temeemi [35] investigated the behavior of RC beams that curved horizontally on elastic foundations using the finite element method, considering material nonlinearity for steel and concrete. Using a 60 degrees of freedom 20-node isoperimetric brick element, the concrete was modeled. Within the brick elements, an axial member was used for reinforcing bars modeling. To model soil, normal reactions (models of Kondner, Winkler and Polynomial) and horizontal reactions of subgrade (model of Winkler) were taken into considerations. The modeling using finite element offered by Al-Temeemi presented an acceptable agreement level concerning the numerical theoretical besides the available experimental results. Some influential parameters related to beams that curved on elastic foundations behavior was investigated; like; boundary conditions, ratio of radius/spanlength $(\mathrm{R} / \mathrm{L}), \alpha 1$ (release of stress rate as the crack width increases), $\alpha 2$ (stress sudden loss at cracking moment), and type of soil. Al-Temeemi's results showed that rising $(\mathrm{R} / \mathrm{L})$ might rise the ultimate load: $40 \%$ when rising $\mathrm{R} / \mathrm{L}$ from 1 to 5 . The steel bars of shear have a significant influence on the curved beams ultimate load; ultimate load reduces by $51 \%$ due to removing shear steel bars.

In 1978, Hsu et al. [36] investigated the forces redistribution of torque and flexure in RC curved beams when cracks appear. The current investigation was conducted to present more appropriate designs in terms of post-cracking in beams. The authors tested seven beams that horizontally curved; $2.74 \mathrm{~m}$ radius and 90 degrees subtended angle. All seven fixed at both ends beams were tested using a mid-span concentrated load as shown in Table 2. Conventional design methods were used to analyze the first and second beams on non-cracked members; the elastic theory was utilized for reinforcement design depending on the ACI Building Code (1971). According to elastic theory for non-cracked sections, the $3^{\text {rd }}$ and $4^{\text {th }}$ beams were also designed based on maximum torsional moment. The $5^{\text {th }}$ and $6^{\text {th }}$ beams were designed based on the cracked sections calculations. The $7^{\text {th }}$ one was modeled as an unchanging beam with longitudinal bars and stirrups. About cracked sections, the post-cracking rigidity of torsion was used to find the rigidity of torsion that was gotten from Hsu (1972) space truss analogy. During testing failure of the seven beams, Hsu et al. noticed that cracking initiation leads to a significantly redistributed of flexural and torsional moments. Results show that early yielding was realized at the beams supports that traditionally modeled, ACI 318-71 and elastic analysis, i.e., noncracked. Accordingly, Hsu et al. stated that the beam design should be linked to elastic analysis. 
Table 2. Test results [36].

\begin{tabular}{|c|c|c|c|c|c|}
\hline \multirow[t]{2}{*}{ BEAM } & \multicolumn{2}{|c|}{$\begin{array}{l}\text { CALCULATED } \\
\text { YIELD LOAD } \\
\text { (kips) }\end{array}$} & \multirow{2}{*}{$\begin{array}{l}\text { ULTIMATR } \\
\text { LOAD } \\
\text { (Kips) }\end{array}$} & \multirow[t]{2}{*}{$\begin{array}{l}\text { COLLAPSE * } \\
\text { MECHARISMS }\end{array}$} & \multirow{2}{*}{$\begin{array}{l}\text { TYPE OF } \\
\text { FAILURE }\end{array}$} \\
\hline & SLPPORT & MIDSPAN & & & \\
\hline HCB-1 & 18.8 & 18.6 & 21.5 & & $\begin{array}{l}\text { Flexural } \\
\text { (Secondary } \\
\text { Torgional) }\end{array}$ \\
\hline $\mathrm{HCE}-2$ & 31.6 & 29.1 & 30.0 & & $\begin{array}{l}\text { Flexural } \\
\text { (Secondary } \\
\text { Toralond1) }\end{array}$ \\
\hline $\mathrm{HCB}-3$ & 30.2 & 28.5 & 17.5 & & $\begin{array}{l}\text { Brittle } \\
\text { Shear and } \\
\text { Torsion }\end{array}$ \\
\hline $\mathrm{HCE}-4$ & 18.7 & 18.3 & 15.0 & & Torstonal \\
\hline $\mathrm{HCB}-5$ & 15.0 & 16.2 & 20.0 & & $\begin{array}{l}\text { Flexurai } \\
\text { (Secondary } \\
\text { Torsional) }\end{array}$ \\
\hline HCB-6 & 23.5 & 24.9 & 24.0 & & $\begin{array}{l}\text { Flexura1 } \\
\text { (Secondary } \\
\text { Torsional) }\end{array}$ \\
\hline $\mathrm{HCB}-7$ & 21.8 & 37.9 & 30.0 & & Tora1onal \\
\hline
\end{tabular}

\footnotetext{
* $\sigma$ Flexural Hinge - Torsional Hinge o Flexura1-Torsional Hinge

$X$ Brittle Fallure in Shear and Torsion
}

In 2010, Al-Tameemi et al. [37] studied the pre and post-cracking behavior of deep RC that horizontally curved. A 3D nonlinear finite element modeling is used to analyze the beams. The ANSYS program concrete modeling was through using a 60 freedom degrees of the 20-node isoperimetric brick element. The reinforced concrete was modeled using bars, represented as axial members embedded inside the concrete brick element. The reinforcing bars are assumed in perfect bond with the surrounding concrete. A numerical and material parametric study was conducted to predict ultimate load capacity besides the load-deflection curve. Specifically, the authors studied the central subtended angle, boundary conditions, and the amount of transverse reinforcement. The aforementioned parameters were studied with different a/d ratios, which led to the conclusion that reducing the angle leads to rise the ultimate capacity.

In 2014, Zhao et al. [38] ran an experimental investigation on the behavior of RC ring beams connected to concrete-filled steel tube (CFST) columns. Testing using low cyclic loading, displacements, collapse patterns, stresses, and dissipation of energy capabilities of three samples was analyzed. The effect of different dimensions of ring beam on the mode of failure and load capacity 
was also studied. In order to validate the method, the experimental phase was matched to the numerical simulation phase. Based on studying the stress distributions of joints without and with the ringed beam, Zhao et al. reached the following conclusions:

1) The classic collapse was the plastic hinges evolution, with no sign.

2) The hysteretic curves of joints' spindle shaped' did not display deteriorating stiffness and strength throughout the test and thus, showed acceptable behavior.

3) The ring beam dimension is a significant factor in the joint connection load capacity. The ratio of displacement ductility, dissipation capacity of energy, and the joint ultimate load capacity are all enhanced by dimension increasing.

In 2016, Wei et al. [39] analyzed a RC ring beam new type experimentally, by joints among CFST columns. Wei et al. studied the behavior of columns and beams that horizontally curved by loading of bidirectional cycle. The suggestions were:

1) The internal forces are affected by the interaction among the CFST column and the ring beam when imposing an exterior force.

2) System of forces is not uni-directional.

3) Multi-directional forces, like axial one, bending, torsion, and shear, must be considered in the $\mathrm{RC}$ ring beams design. In this design way, joints between columns and beams resist seismic loads better and have better ductility.

\section{Main Conclusions}

The most important findings after reading the above articles can be summarized as follows:

1) The plastic approach can be used to analyze RC curved beams, although it depends on plastic hinge formation and the formed sections' conditions.

2) Curved beam ultimate load, interior forces, and failure mode may be forecast by the $1^{\text {st }}$ criterion. The including shear $\left(2^{\text {nd }}\right.$ criterion) is useful, establishing a member nominal strength for ultimate load and internal forces of the ring and curved beams. Additional studies, and mainly experimental data, are required to criteria of yield verification on a variety of material properties and sections. Investigations suggest, in curved beams, that plastic theory is active in estimating how end conditions affect failure modes and ultimate load capacity.

3) Due to the existence of D regions, STM is real for deep members.

4) $\mathrm{RC}$ ring beams are suitable for applications of seismic resistance because they have a great plasticity level.

5) For behavior predicting of reinforced concrete deep beams that curved, the $3 \mathrm{D}$ nonlinear finite element is best.

6) Increasing the central angle leads to a decrease in the strength of curved beams.

7) On the whole, the relationship between a/d ratio and the beam load capacity is an inverse relationship.

8) In reinforced concrete deep ring beams, shear failure is dominant.

9) In general, the relationship between ring beam diameter and the beam load capacity is an inverse relationship.

\section{References}

[1] Anderson, C.G., 1950. Flexural stresses in curved beams of I-and box-section. Proceedings of the Institution of Mechanical Engineers, 163(1), pp.295-306.

[2] Broughton, D.C., Clark, M.E. and Corten, HT, 1950. Tests and Theory of Elastic Stresses in Curved Beams Having I-and T-Sections. Proc. Soc. of Experimental Stress Analysis, 8(1).

[3] Kurtaran, H., 2015. Geometrically nonlinear transient analysis of thick deep composite curved beams with generalized differential quadrature method. Composite Structures, 128, pp.241-250.

[4] Al-Qaicy, H.H.G., Marsono, A.K. and Hejazi, F., 2014. Reinforced Concrete Ring Beams [Nonlinear Finite Element Analysis (NLFEA)]. 
[5] ACI 318-19, 2019. Building Code Requirements for Structural Concrete and Commentary (318R-19) American Concrete Institute, Farmington Hills, Michigan, USA.

[6] Abdul-Razzaq, K.S., Jalil, A.M. and Dawood, A.A., 2020, March. Ring deep beam-A parametric study. In AIP Conference Proceedings (Vol. 2213, No. 1, p. 020128). AIP Publishing LLC.

[7] ACI Committee and American Concrete Institute, 2014. Building Code Requirements for Structural Concrete (ACI 318-14) and Commentary.

[8] Abdul-Razzaq, K.S., Ali, H.I. and Abdul-Kareem, M.M., 2017. A new strengthening technique for deep beam openings using steel plates. International Journal of Applied Engineering Research, 12(24), pp.15935-15947.

[9] Abdul-Razzaq, K.S. and Jebur, S.F., 2017. Suggesting alternatives for reinforced concrete deep beams by reinforcing struts and ties. In MATEC web of conferences (Vol. 120, p. 01004). EDP Sciences.

[10] Abdul-Razzaq, K.S. and Jebur, S.F., 2018. Experimental verification of strut and tie method for reinforced concrete deep beams under various types of loadings. Journal of Engineering and Sustainable Development, 21(6), pp.39-55.

[11] Abdul-Razzaq, K.S., Jebur, S.F. and Mohammed, A.H., 2018. Concrete and steel strengths effect on deep beams with reinforced struts. International Journal of Applied Engineering Research, 13(1), pp.66-73.

[12] Abdul-Razzaq, K.S., Jebur, S.F. and Mohammed, A.H., 2018. Strut and tie modeling for RC deep beams under non-central loadings. Civil Engineering Journal, 4(5), pp.937-948.

[13] Abdul-Razzaq, K.S., 2015. Effect of heating on simply supported reinforced concrete deep beams. Diyala Journal of Engineering Sciences, 8(2), pp.116-133.

[14] Abdul-Razzaq, K.S. and Jalil, A.M., Behavior of Reinforced Concrete Continuous Deep Beams.

[15] Jalil, A.M., Hamood, M.J., Abdul-Razzaq, K.S. and Mohammed, A.H., 2018. Applying different decentralized loadings on RC continuous deep beams using STM. International Journal of Civil Engineering and Technology, 9(11), pp.2752-2769.

[16] Jalil, A.M., Hamood, M.J., Abdul-Razzaq, K.S., and Mohammed, A.H., 2018. Applying different decentralized loadings on RC continuous deep beams using STM. International Journal of Civil Engineering and Technology, 9(11), pp.2752-2769.

[17] Mohammedali, T.K., Jalil, A.M., Abdul-Razzaq, K.S. and Mohammed, A.H., 2019. STM experimental verification for reinforced concrete continuous deep beams. International Journal of Civil Engineering and Technology (IJCIET), 10(2), pp.2227-2239.

[18] Abdul-Razzaq, K.S., Jalil, A.M. and Dawood, A.A., 2020, March. Reinforced concrete continuous deep beams under the effect of different parameters. In AIP Conference Proceedings (Vol. 2213, No. 1, p. 020127). AIP Publishing LLC.

[19] Abdul-Razzaq, K.S., Jalil, A.M. and Dawood, A.A., 2021. Reinforcing struts and ties in concrete continuous deep beams. Engineering Structures, 240, p.112339.

[20] Abdul-Razzaq, K.S. and Farhood, M.A., 2017. Design and behavior of reinforced concrete pile caps: a literature review. International Journal of Engineering Research and science \& Technology, 6(4).

[21] Abdul-Razzaq, K.S. and Farhood, M.A., 2019. Design-oriented testing and modeling of reinforced concrete pile caps. KSCE Journal of Civil Engineering, 23(8), pp.3509-3524.

[22] Dawood, A.A., Kadhum, A.K. and Abdul-Razzaq, K.S., 2018. Strength of reinforced concrete corbels-a parametric study. International Journal of Civil Engineering and Technology (IJCIET), 9(11), pp.2274-2288.

[23] Abdul-Razzaq, K.S. and Dawood, A.A., 2020, August. Corbel strut and tie modelingExperimental verification. In Structures (Vol. 26, pp. 327-339). Elsevier.

[24] Abdul-Razzaq, K.S., Dawood, A.A. and Mohammed, A.H., 2019, May. A review of previous studies on the reinforced concrete corbels. In IOP Conference Series: Materials Science and Engineering (Vol. 518, No. 2, p. 022057). IOP Publishing. 
[25] Abdul-Razzaq, K.S., Dawood, A.A. and Jalil, A.M., 2020, March. Analysis and design of RC wide corbels-Suggested procedure. In AIP Conference Proceedings (Vol. 2213, No. 1, p. 020112). AIP Publishing LLC.

[26] Abdul-Razzaq, K.S., Dawood, A.A. and Jalil, A.M., 2020, March. Analysis of unsymmetrical reinforced concrete double corbels. In AIP Conference Proceedings (Vol. 2213, No. 1, p. 020113). AIP Publishing LLC.

[27] Abdul-Razzaq, K.S. and Dawood, A.A., 2021. Reinforcing Struts and Ties in Concrete Corbels. ACI Structural Journal, 118(4).

[28] Dawood, A.A. and Abdul-Razzaq, K.S., 2021. Shear Friction and Strut-and-Tie Modeling Verification for Pier Caps. Journal of Bridge Engineering, 26(9), p.04021059.

[29] Abdul-Razzaq, K.S., Abed, A.H. and Ali, H.I., 2016. Parameters affecting load capacity of reinforced self-compacted concrete deep beams. International Journal of Engineering, 5(05).

[30] Badawy, H.E.I., McMullen, A.E. and Jordaan, I.J., 1977. Experimental investigation of the collapse of renforced concrete curved beams. Magazine of Concrete Research, 29(99), pp.59-69.

[31] Abdul-Razzaq, K.S., Jalil, A.M. and Dawood, A.A., 2020, March. Ring deep beam-A parametric study. In AIP Conference Proceedings (Vol. 2213, No. 1, p. 020128). AIP Publishing LLC.

[32] Mansur, M.A. and Rangan, B.V., 1981, May. Study of design methods for reinforced concrete curved beams. In Journal Proceedings (Vol. 78, No. 3, pp. 226-254).

[33] Al-Mutairee, H.M.K., 2013. Effect of non-uniform distribution of longitudinal reinforcement on the behavior of reinforced concrete horizontally curved beams with fixed-ends. J. Univ. Babylon, 21(3), pp.826-838.

[34] Al-Azzawi, A.A. and Shaker, A.S., 2011. Finite difference analysis of curved deep beams on Winkler foundation. ARPN Journal of Engineering and Applied Sciences, 6(3).

[35] Al-Temeemi M. A, 2002. Nonlinear analysis of reinforced concrete horizontally curved beams on elastic foundation. M.Sc. Thesis, University of Babylon, Iraq.

[36] Hsu, T.T., Inan, M. and Fonticiella, L., 1978, April. Behavior of reinforced concrete horizontally curved beams. In Journal Proceedings (Vol. 75, No. 4, pp. 112-123).

[37] Al-Tameemi, H.A., Ali, A.P.D.A.Y. and Attiyah, A.N., 2010. Three-dimensional nonlinear finite element analysis of reinforced concrete horizontally curved deep beams. Journal of Babylon University/Engineering Sciences, 18(1).

[38]Zhao, Y., Xu, L.H. and Liu, B., 2014. Seismic Behavior of Reinforced Concrete Beam to Concrete-Filled Steel Tubular Column Connections with Ring-Beam. In International Efforts in Lifeline Earthquake Engineering (pp. 489-496).

[39] Wang, W., Chen, Y. and Li, W., Experimental Investigation on New Ring-Beam Connections for a Concrete-Filled Tubular Column and RC Beam. In Composite Construction in Steel and Concrete VII (pp. 108-119). 